\title{
USULAN PENGEMBANGAN BISNIS RURAL LOGISTICS E-COMMERCE DI PT. POS INDONESIA (PERSERO)
}

\author{
Andri Gunawan \\ PT. Pos Indonesia (Persero) \\ Jl. Cilaki No.73 Bandung \\ dzikran.arfa@gmail.com
}

\begin{abstract}
Abstrak
Wilayah pedesaan memiliki pasar yang sangat potensial untuk dikembangkan oleh industri perusahaan logistik, karena memiliki permintaan yang cukup besar terhadap kebutuhan barang di pedesaan dimana internet pun sudah mulai popular di masyarakat pedesaan. Fenomena tersebut menjadi peluang bagi PT. Pos Indonesia untuk membangun bisnis layanan logistik dengan dibentuknya divisi integrasi logistik untuk mengelola semua aktivitas bisnis logistik. Namun pada kenyataannya kinerja pendapatan bisnis logistik PT. Pos Indonesia masih sangat kecil. Salah satu penyebab belum optimalnya kinerja bisnis logistik PT. Pos Indonesia adalah belum jelasnya konsep bisnis yang akan dilakukan. Pada penelitian ini usulan pengembangan bisnis rural logistics e-commerce dilakukan secara menyeluruh berdasarkan acuan utama Dong Haoping (2010) yaitu dalam mengembangkan bisnis rural logistics e-commerce dengan menggunakan jaringan pos yang dimiliki sampai daerah pedesaan. Hasil dari usulan konsep bisnis baru PT. Pos Indonesia adalah dengan mengembangkan model bisnis rural logistic yang diikuti dengan bisnis platform e-commerce dimana PT. Pos Indonesia berperan sebagai penyedia jasa logistik pedesaan. Dengan adanya jasa layanan rural logsitics $e$ commerce tersebut diharapkan memudahkan jangkauan masyarakat pedesaan maupun perkotaan untuk mendapatkan kebutuhan pokok mereka masingmasing dengan kestabilan harga dan ketersediaan barang yang dapat terkendali, disamping meningkatkan kinerja perusahaan.
\end{abstract}

Kata kunci: Model Bisnis, Rural Logistics Ecommerce, Logistik

\section{Abstract}

Rural areas have a very potential market to be developed by the logistics company industry, because they have a significant demand for goods in rural areas where the internet has become popular in rural communities. This phenomenon is an opportunity for PT. Pos Indonesia to build a logistics service business by forming a logistics integration division to manage all logistics business activities. But in reality the performance of the logistics business income of PT. Pos Indonesia is still very small. One of the causes is the non-optimal performance of the logistics business of PT. Pos Indonesia is not yet clear the concept of business to be carried out. In this research, the proposal to develop a rural logistics e-commerce business is carried out thoroughly based on the main reference of Dong Haoping (2010), namely in developing rural logistics e-commerce business by using the postal network owned to rural areas. The results of the proposed new business concept of PT. Pos Indonesia is developing a rural logistic business model that is followed by an e-commerce business platform where PT. Pos Indonesia acts as a provider of rural logistics services. With the availability of rural logitics e-commerce services, it is expected to facilitate the reach of rural and urban communities to obtain their respective basic needs with price stability and availability of goods that can be controlled, while improving company.

Performance

Keywords: Business Model, Rural Logistics Ecommerce, Logistics.

\section{Pendahuluan}

Saat ini bisnis logistik menjadi bisnis yang sangat potensial, meski terlihat sederhana proses bisnis logistik itu, tetapi potensi pasarnya luar biasa. Berdasarkan data Frost \& Sullivan (2014), hingga akhir tahun 2014 market size logistik di Indonesia 
mencapai sekitar Rp 1.800 triliun, setara dengan APBN 2014 (Rp 1.816,7 triliun). Bisnis logistik tidak hanya berada di wilayah perkotaan, namun juga berada di wilayah pedesaan (rural). Zeng Ting, et al (2013) memaparkan wilayah pedesaan memiliki pasar yang sangat potensial untuk dikembangkan oleh industri perusahaan logistik, karena memiliki permintaan yang cukup besar terhadap kebutuhan barang di pedesaan dimana internet pun sudah mulai popular di masyarakat pedesaan. Hal ini menjadi prospek yang sangat bagus bagi perusahaan logistik nuntuk mengekspansi bisnis di area pedesaan di tahun-tahun mendatang. Fenomena tersebut menjadi peluang bagi PT. Pos Indonesia untuk membangun bisnis layanan logistik dengan dibentuknya divisi integrasi logistik untuk mengelola semua aktivitas bisnis logistik. Namun pada kenyataannya kinerja pendapatan bisnis logistik PT. Pos Indonesia masih sangat kecil. Salah satu penyebab belum optimalnya kinerja bisnis logistik PT. Pos Indonesia adalah belum jelasnya konsep bisnis yang akan dilakukan.

Pada penelitian ini usulan pengembangan bisnis rural logistics e-commerce dilakukan secara menyeluruh berdasarkan acuan utama Dong Haoping (2010) yaitu dalam mengembangkan bisnis rural logistics e-commerce dengan menggunakan jaringan pos yang dimiliki sampai daerah pedesaan. Dari uraian di atas pengembangan bisnis logistik yang akan dilakukan adalah terkait dengan pengembangan bisnis logistik pedesaan (rural logistics) berbasis e-commerce dengan menghasilkan bisnis model rural logistics.

Tujuan yang ingin dicapai dari penelitian ini adalah menghasilkan konsep bisnis logistik pedesaan berbasis e-commerce yang dapat meningkatkan kinerja perusahaan di masa yag akan datang.

\section{KAJIAN LITERATUR}

\section{II.1 Model Bisnis Osterwalder}

Menurut Osterwalder (2010) bisnis model menjelaskan mengenai dasar pemikiran sebuah bisnis diciptakan, diberikan dan ditangkap nilainya. Osterwalder membuat sebuah pendekatan model kanvas yaitu "Nine Building Blocks" yang memudahkan bagi para pebisnis untuk membangun dan mengembangkan bisnis mereka. Nine Buiding Blocks terdiri dari: value propositions, target customer, distribution channel, relationship, value configuration, capability, partnership, cost structure, revenue model.
Berikut ini akan dijabarkan penjelasan mengenai nine building blocks tersebut:

1. Value Proposition

Menurut Osterwalder \& Pigneur (2010) proposisi nilai menggambarkan bagaimana pelanggan dapat beralih dari satu perusahaan ke perusahaan lain melalui produk atau layanan yang ditawarkan oleh perusahaan yang berbeda dengan para kompetitornya.

2. Target Customer

Menurut Osterwalder (2010), pelanggan merupakan kunci utama dalam mendapatkan keuntungan, tanpa pelanggan maka sebuah perusahaan tidak dapat bertahan lama dalam bisnis yang mereka bangun.

3. Distribution Channels

Distribution Channels menggambarkan bagaimana sebuah perusahaan dapat menjalin komunikasi dengan pelanggannya dalam menyampaikan nilai proporsisinya

4. Relationship

Hubungan dengan pelanggan dibangun sesuai dengan segmen pelanggan, dikarenakan setiap segmentasi memiliki perbedaan. Dalam menjalin hubungan yang baik dengan pelanggan dapat dilakukan dengan tiga cara yaitu: customer acquisition, customer retention dan upselling.

5. Value Configuration

Pengaturan sumber daya yang diperlukan untuk menciptakan nilai bagi pelanggan. Setiap model bisnis membutuhkan sumber daya.

\section{Capability}

Kemampuan untuk melaksanakan pola tindakan yang dapat diulang yang diperlukan untuk menciptakan nilai bagi pelanggan.

7. Partnership

Perusahaan membentuk aliansi atau kerjasama karena berbagai alasan. Biasanya perusahaan menciptakan untuk mengoptimalkan bisnis, mengurangi terjadinya resiko dan untuk memiliki daya saing yang tinggi dengan para kompetitornya.

8. Cost Structure

Struktur biaya menggambarkan semua biaya yang dibutuhkan untuk menjalankan suatu model bisnis. Biaya dapat diperhitungkan dengan baik jika aktifitas utama, sumber daya utama dan kemitraan telah ditentukan. Cost structure dari bisnis model dapat dibedakan menjadi dua bagian yaitu: 
a. Cost driven yaitu model yang berfokus pada penekanan biaya serendah mungkin. Pendekatan ini bertujuan untuk mempertahankan struktur biaya agar lebih ramping, menggunakan proposisi nilai dengan harga rendah.

b. Value driven: perusahaan yang tidak terlalu mementingkan biaya yang akan muncul dalam mendesain sebuah bisnis model dan lebih fokus terhadap penciptaan nilai.

\section{Revenue Model}

Menjelaskan cara perusahaan menghasilkan uang melalui berbagai aliran pendapatan. Sebuah bisnis model dapat melibatkan dua tipe revenue yang berbeda antara lain:

a. Transaction Revenues yaitu transaksi yang diperoleh dari sekali pembayaran dari pelanggan.

b. Recurring Revenues yaitu transaksi yang diperoleh dari pembayaran yang masih berkelanjutan untuk memberikan value proposition kepada pelanggan dan menyediakan layanan customer support kepada pelanggan setelah pembelian.

\section{II.2 Service Positioning Analysis (SPA)}

Model ini membahas tentang analisis posisi strategi perusahaan sebelum masuk ke model bisnis. Pada tahapan ini menjelaskan tentang hubungan antara tipe layanan yang dimiliki (type of service) dengan tipe saluran distribusi (type of channel) sehingga menggambarkan posisi strategis perusahaan dalam sebuah matrix seperti gambar di bawah ini:

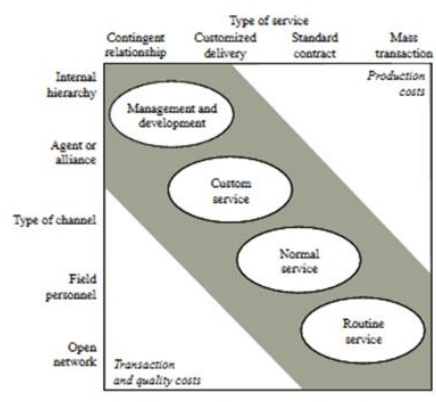

Gambar 1 SPA Matrix Sumber: Tinila, et al (1995)

Tipe layanan (type of service) tersebut dimulai dari mass transaction, customized services sampai contingent realationships. Sementara layanan saluran distribusi (type of channel) mulai dari internal hierarchies sampai open networks seperti internet. Ouput dari layanan adalah berada pada diagonal matriks yang merupakan kombinasi antar kedua tipe yakni tipe layanan dan tipe saluran.

\section{II.3 Peraturan Pemerintah Tentang Logistik dan Ecommerce}

Sub bab ini berisi tentang peraturan pemerintah berkaitan dengan sistem logistik nasional dan road map ecommerce.

1. Deskripsi Program Pemerintah Tentang Sislognas

Peraturan Presiden no.26 tahun 2012 tentang Cetak Biru Sistem Logistik Nasional Pemerintah melalui Perpres No.32 Tahun 2011 tentang masterplan percepatan dan perluasan pembangunan ekonomi Indonesia (MP3EI) 2011-2015. Blue Print Sislognas adalah mewujudkan system logistik yang terintegrasi, efektif dan efisien untuk meningkatkan daya saing nasional di pasar regional dan global, serta untuk meningkatkan kesejahteraan masyarakat. PT Pos Indonesia (Persero) diharapkan meningkatkan perannya dalam mewujudkan sistem logistik yang terintegrasi dengan menjadi backbone logistik nasional dan membangun sistem logistik pedesaan.

2. Deskripsi Perpres No. 74 Tahun 2017 Tentang Road Map E-Commerce

Bahwa ekonomi berbasi elektronik mempunyai potensi ekonomi yang tinggi bagi Indonesia dan merupakan salah satu tulang punggung perekonomian nasional, sehingga dalam rangka mengoptimalkan pemanfaatan potensi ekonomi berbasis elektronik, pemerintah perlu mendorong percepatan dan pengembangan system perdagangan nasional berbasis elektronik (e-commerce), usaha pemula (start-up), pengembangan usaha dan percepatan logistik dengan menetapkan peta jalan sistem perdagangan nasional berbasis elektronik (road map e-commerce) yang terintegrasi.

\section{II.4 Penelitian Dong Haoping tahun 2010}

Dong Haoping (2010) dalam papernya yang berjudul "Henan Post Logistics Service Innovation and Market Expansion" menjelaskan tentang 
pengembangan bisnis baru dengan melakukan inovasi layanan logistik pada perusahaan Pos Henan. Dalam model tersebut ditekankan untuk melakukan inovasi layanan logistik yakni dengan mengembangkan pasar rural postal dan mengembangkan platform $e$ commerce yang menawarkan layanan belanja online. Inovasi layanan logistik tersebut mempertimbangkan kekuatan jaringan fisik yang dimiliki dan kelemahan yang dimiliki. Henan pos logistik memiliki kekuatan dan peluang pengembangan, tetapi bukan berarti tidak ada tantangan dan hambatan. Dalam penelitian ini ditekankan untuk menggunakan keunggulan jaringan yang dimiliki dan menambah kekuatan untuk menyediakan solusi logistik terpadu.

\section{II.5 Penelitian Kandampully tahun 2002}

Kandampully (2002) dalam papernya yang berjudul "Innovation in logistic services and the new business model" mengemukakan ada tiga kebutuhan untuk inovasi layanan logistik yaitu:

\section{Inovasi logistik melalui teknologi}

2. Inovasi logistik melalui pemgetahuan

\section{Inovasi logistik melalui jaringan hubungan}

\section{Analisis dan Perancangan}

Penelitian ini bertujuan untuk merancang model isnis baru PT Pos Indonesia dengan menggunakan model acuan utama Dong Haoping (2010). Model Dong Haoping (2010) mengkaji tentang inovasi layanan logistik dan ekspansi pasar pada perusahaan Henan Post Logistik, dimana bisnis eksisting yang dilakukan berkaitan dengan bisnis pos seperti surat, paket dan jasa layanan keuangan. Seiring dengan perkembangan teknologi dan persaingan yang semakin kompetitif di bisnis tersebut, produk layanan yang dimiliki sudah tidak dapat secara penuh memenuhi kebutuhan pasar. Untuk itu dibutuhkan inovasi layanan logistik dengan mempertimbangkan kekuatan jaringan fisik yang dimiliki dan kelemahan yang dimiliki. Dalam model tersebut ditekankan untuk melakukan inovasi layanan logistik yakni dengan mengembangkan pasar rural postal dan mengembangkan platform e-commerce yang menawarkan layanan belanja online.

\section{III.1 Analisis Sistem Logistik Eksisting PT. Pos Indonesia}

Setelah dilakukan pemetaan system logistik terhadap kondisi bisnis eksisting saat ini dibandingkan dengan Divisi Surat \& Paket (Ratket) dan anak perusahaan PT. Pos Logistik Indonesia, maka terdapat kesamaan konsep dan aktivitas bisnis antara ketiganya, seperti di bawah ini:

Tabel 1 Pemetaan Sistem Logistik PT. Pos Indonesia (Persero)

\begin{tabular}{|c|c|c|c|c|}
\hline NO & Jenis & $\begin{array}{c}\text { Direktorat } \\
\text { Integrasi Logistik }\end{array}$ & $\begin{array}{c}\text { Direktorat } \\
\text { Surat \& Paket }\end{array}$ & $\begin{array}{c}\text { Anak Perusahaan } \\
\text { PT Pos Logistik } \\
\text { Indonesia } \\
\end{array}$ \\
\hline 1 & Objek & $\begin{array}{l}\text { Contoh: } \\
\text { Kiriman Korporat: } \\
\text { Kiriman Kementrian } \\
\text { perikanan (alat } \\
\text { penangkap } \\
\text { ikan),kiriman } \\
\text { kementrian } \\
\text { kesehatan (alat-alat } \\
\text { kesehatan), pilkada }\end{array}$ & $\begin{array}{l}\text { Barang: } \\
\text { - Kiriman retail } \\
\text { - Surat/ } \\
\quad \text { Dokumen } \\
\text { - Paket (berat } 0 \\
\quad \text { s.d } 30 \mathrm{~kg} \text { ) } \\
\text { - Kiriman Korporat } \\
\text { (Sifat Project) } \\
\text { (kiriman } \\
\text { pemerintah, } \\
\text { swasta/manufkatur) } \\
\text { Contoh: } \\
\text { Kiriman Retail : } \\
\text { Kiriman dari walking } \\
\text { customer melalui } \\
\text { loket Kantor Pos : } \\
\text { Surat Kilat Khusus, } \\
\text { Paket Pos Kilat Khusus } \\
\text { dll } \\
\text { Contoh: } \\
\text { Kiriman Korporat: } \\
\text { Kiriman Kementrian } \\
\text { sosial (kartu } \\
\text { KKS,kiriman } \\
\text { kementrian } \\
\text { kesehatan (alat-alat } \\
\text { kesehatan), pilkada }\end{array}$ & 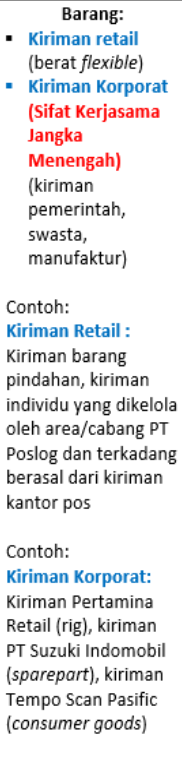 \\
\hline 2 & Sumber & $\begin{array}{l}\text { Destination: } \\
\text { End user customer } \\
\text { Kiriman Korporat } \\
\text { Origin: } \\
\text { Mulai dari } \\
\text { pengirim/shipper } \\
\text { (perusahaan } \\
\text { BUMN,kementrian } \\
\text { \&swasta) yang proses } \\
\text { operasionalnya } \\
\text { melibatkan kantor } \\
\text { pos cabang seluruh } \\
\text { Indonesia }\end{array}$ & $\begin{array}{l}\text { Destination: } \\
\text { End user customer } \\
\text { Kiriman Korporat } \\
\text { Origin: } \\
\text { Mulai dari } \\
\text { pengirim/shipper } \\
\text { (perusahaan } \\
\text { BUMN,kementrian } \\
\text { \&swasta) yang proses } \\
\text { operasionalnya } \\
\text { melibatkan kantor } \\
\text { pos cabang seluruh } \\
\text { Indonesia }\end{array}$ & $\begin{array}{l}\text { Kiriman Retail } \\
\text { Origin: } \\
\text { Area Pos Logistik di } \\
\text { seluruh wilayah } \\
\text { Indonesia dan } \\
\text { terkadang kantor pos } \\
\text { cabang seluruh } \\
\text { Indonesia/ pick up } \\
\text { service dari customer } \\
\text { Destination: } \\
\text { End user customer } \\
\text { Kiriman Korporat } \\
\text { Origin: } \\
\text { Mulai dari } \\
\text { pengirim/shipper } \\
\text { (perusahaan } \\
\text { BUMN,kementrian } \\
\text { \&swasta) yang proses } \\
\text { operasionalnya } \\
\text { dilakukan oleh PT Pos } \\
\text { Logistik Indonesia }\end{array}$ \\
\hline
\end{tabular}




\begin{tabular}{|l|l|l|l|l|}
\hline NO & \multicolumn{1}{|c|}{ Jenis } & \multicolumn{1}{|c|}{$\begin{array}{c}\text { Direktorat } \\
\text { Integrasi Logistik }\end{array}$} & \multicolumn{1}{|c|}{$\begin{array}{c}\text { Direktorat } \\
\text { Surat \& Paket }\end{array}$} & $\begin{array}{l}\text { Anak Perusahaan } \\
\text { PT Pos Logistik } \\
\text { Indonesia }\end{array}$ \\
\hline 3 & Letak & $\begin{array}{l}\text { Antara Origin \& } \\
\text { Destination } \\
\text { Penyedia Jasa } \\
\text { Logistik }\end{array}$ & $\begin{array}{l}\text { Antara Origin \& } \\
\text { Destination } \\
\text { Penyedia Jasa } \\
\text { Logistik }\end{array}$ & $\begin{array}{l}\text { Antara Origin \& } \\
\text { Destination } \\
\text { Penyedia Jasa } \\
\text { Logistik }\end{array}$ \\
\hline 4 & $\begin{array}{l}\text { Tata Niaga } \\
\text { (Proses } \\
\text { Bisnis) }\end{array}$ & Penyedia Jasa Logistik & Penyedia Jasa Logistik & $\begin{array}{l}\text { Penyedia Jasa } \\
\text { Logistik }\end{array}$ \\
\hline 5 & $\begin{array}{l}\text { Tata Kelola } \\
\text { (Struktur } \\
\text { Organisasi) }\end{array}$ & $\begin{array}{l}\text { Struktur Organisasi } \\
\text { Induk PT Pos } \\
\text { Indonesia dibawah } \\
\text { Direktur Integrasi } \\
\text { Logistik }\end{array}$ & $\begin{array}{l}\text { Struktur Organisasi } \\
\text { Induk PT Pos } \\
\text { Indonesia dibawah } \\
\text { Direktur Surat \& } \\
\text { Paket }\end{array}$ & $\begin{array}{l}\text { Struktur Organisasi } \\
\text { terpisah sebagai } \\
\text { anak perusahaan di } \\
\text { bawah kendali } \\
\text { Holding PT Pos } \\
\text { Indonesia }\end{array}$ \\
\hline
\end{tabular}

Melihat kondisi tersebut maka dibentuknya Divisi Integrasi Logistik masih memiliki kesamaan konsep bisnis yang bersinggungan dengan aktivitas bisnis dua divisi lain di PT. Pos Indonesia.

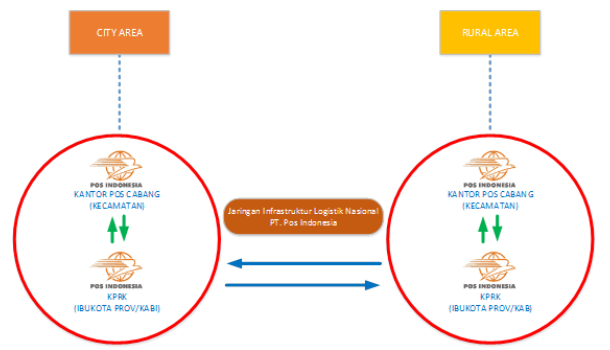

Gambar 2 Jaringam Infrastruktur Logistik PT.Pos
Indonesia

Jaringan infrastruktur logistik yang dimiliki oleh PT. Pos Indonesia yang terhubung di seluruh ibukota kabupaten/kota di seluruh wilayah Indonesia dan bercabang ke setiap kecamatan hingga ke pelosok desa menjadi kekuatan perusahaan yang tidak dimiliki oleh perusahaan lain sejenis di Indonesia. Keunggulan dari jaringan yang dimiliki oleh PT. Pos Indonesia adalah biaya distribusi ke wilayah pedesaan (rural) akan menjadi lebih murah dibandingkan dengan perusahaan lain membangun sendiri jaringan menuju wilayah pedesaan (rural) untuk mendistribusikan komoditasnya, karena PT. Pos Indonesia memiliki jaringan fisik dan asset tetap lainnya yang tersebar sampai pelosok pedesaan.

\section{III.2 Analisis Posisi Strategi Perusahaan}

Berdasarkan kekuatan dan peluang yang dimiliki, maka akan dirancang model bisnis baru PT. Pos Indonesia (Persero) yakni model bisnis rural logistics ecommerce. Sebelum dilakukan perancangan model bisnis baru, maka dilakukan analisis posisi layanan perusahaan menggunakan SPA model (Tinila, et al.1995) untuk melihat kombinasi antara tipe layanan dengan tipe saluran distribusi.

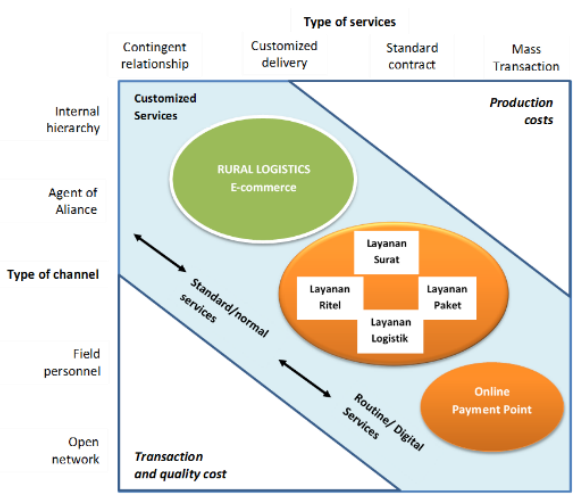

Gambar 3 SPA Matriks Layanan PT.Pos Indonesia

SPA (Service Positioning Analysis) adalah kerangka untuk menganalisis hubungan dan layanan pada tingkat strategik. Dalam model SPA, proses layanan yang efisien terlihat pada kombinasi antara karakteristik layanan dan saluran pengiriman layanan. Tipe layanan dimulai dari transaksi masal sampai ke contingent relationships, sementara saluran pengiriman layanan dimulai dari hirarki internal sampai jaringan terbuka seperti internet. PT. Pos Indonesia (Persero) memiliki produk layanan eksisting yang terbagi ke dalam dua kelompok besar berdasarkan matriks SPA tersebut:

1. Layanan routine/digital services (layanan online payment point)

Pada SPA matrix, layanan online payment point berada pada kategori routine/digital service dimana melayani transaksi massal (mass transaction) untuk sektor publik dan perusahaan yang menawarkan jenis layanan pembayaran secara online berupa pembayaran rekening atau tagihan dari pelanggan mitra kerja perusahaan. Layanan online payment point ini memudahkan pelanggan dalam melakukan pembayaran rekening atau tagihan setiap bulannya. Akses saluran distribusi pelayanan memiliki 2.700 outlet di seluruh Indonesia berupa kantor pos cabang dan mobil pos keliling. Layanan tersebut merupakan kombinasi antara layanan standar dengan tipe saluran layanan jaringan terbuka (open network).

2. Layanan standard/normal (layanan surat pos, paket pos, logistik dan ritel) 
Pada SPA matriks, layanan surat pos, paket pos, logistik dan ritel berada pada kategori standard/normal services yang merupakan kombinasi antara layanan standar dengan tipe saluran layanan melalui service personnel yang berada pada outlet-outlet cabang kantor pos yang tersebar di seluruh Indonesia. Hal ini tentu saja membutuhkan tenaga kerja yang cukup banyak untuk melayani pelanggan baik itu pelanggan individu ( $B$ to $C$ ) maupun pelanggan korporat (B to B). Berikut layanan eksisting yang dimiliki oleh PT. Pos saat ini yaitu:

a. Layanan suratpos

b. Layanan paketpos

c. Layanan logistik

d. Layanan ritel

Usulan dalam penelitian ini adalah mengembangkan layanan bisnis rural logistics $e$ commerce yang merupakan kombinasi antara tipe layanan yang customized dan tipe saluran yang mengandalkan aliansi atau partnership. Hal ini akan mengubah kondisi bisnis eksisting perusahaan, dimana adanya pemanfaatan asset sarana produksi di kantor pos cabang kecamatan yang berperan menjadi post mart dan kantor pos ibukota kabupaten/provinsi yang berperan menjadi pusat distribusi (distribution center). PT. Pos Indonesia sudah memiliki jaringan fisik logistik yang tersebar sampai ke pelosok kecamatan hinga daerah terpencil, sehingga pemanfaatan jaringan fisik tersebut dapat menunjang aktivitas physical logstik bagi rural. Sedangkan untuk jaringan komunikasi dan teknologi, yakni dengan adanya platform e-commerce, maka diperlukan pengembangan ICT (Information Communication Technology) untuk membangun platform e-commerce tersebut. Ada dua alternatif pengembangan platform e-commerce tersebut, yakni:
1. Melakukan partnership atau aliansi dengan perusahaan e-commerce yang sudah establish saat ini di Indonesia seperti Lazada, Bukalapak, Shopee, Tokopedia, Balanja.com, Blibli.com.

2. Membangun dan mengembangkan sendiri platform e-commerce yang sebenarnya sudah pernah dilakukan oleh PT. Pos Indonesia dengan produk layanan Galeripos.com.

\section{III.3 Perancangan Model Bisnis Baru}

Setelah melakukan analisis posisi layanan (SPA model) pada tingkat perencanaan strategi layanan perusahaan dimana dihasilkan layanan baru berupa rural logistics e-commerce, maka tahap selanjutnya adalah merancang model bisnis pada level unit bisnis menggunakan building blocks of business model (Osterwalder.2004).

Tabel 2 Model Bisnis Usulan Baru

\begin{tabular}{|c|c|c|}
\hline No & $\begin{array}{c}\text { Building block } \\
\text { of business } \\
\text { model }\end{array}$ & Rural Logistics E-Commerce \\
\hline 1 & $\begin{array}{c}\text { Value } \\
\text { proposition }\end{array}$ & Speed \& Ease of Logistics Service \\
\hline 2 & $\begin{array}{c}\text { Target } \\
\text { customer }\end{array}$ & B to B \& individual customer \\
\hline 3 & $\begin{array}{c}\text { Distribution } \\
\text { channel }\end{array}$ & Outlet pos \& agen pos \\
\hline 4 & Relationship & Kontrak Multiyear \\
\hline 5 & $\begin{array}{c}\text { Value } \\
\text { configuration }\end{array}$ & Layanan logistik internal \& partners \\
\hline 6 & Capability & Jaringan Rural \\
\hline 7 & Partnership & Jaringan internal \& partner \\
\hline 8 & Cost structure & Fixed Cost Jaringan \\
\hline 9 & $\begin{array}{c}\text { Revenue } \\
\text { model }\end{array}$ & Contract based fee \\
\hline
\end{tabular}

Dari layanan eksiting yang dimiliki perusahaan dapat diketahui bahwa dari aspek value proposition layanan yang dimiliki masih bersifat standar dan dari segi relationship masih berdasarkan transaksi, oleh karena itu akan dijelaskan model bisnis dari layanan rural logistics e-commerce yang memiliki value proposition dengan speed \& ease of logistics service dan relationship yang memiliki kontrak multi year berikut ini:

1. Value proposition: nilai layanan menggunakan layanan customized dan relationship yang mengandalkan layanan kerjasama dengan para stakeholders terkait juga berdasarkan pesanan khusus dari pelanggan, sehingga memberikan layanan logistik yang cepat dan mudah bagi pelanggan (Speed \& Ease of Logistics Service). 
2. Target customer: target pelanggan dari layanan ini adalah masyarakat rural (pedesaan) seperti petani, masyarakat urban (perkotaan) juga pelanggan korporat business to business yang terikat dengan kontrak kerja dalam jangka waktu tertentu seperti perusahaan pengolahan makanan, perusahaan ritel mini market dan industri makanan.

3. Distribution channel: saluran pelayanan yang digunakan adalah menggunakan outlet pos kantor pos cabang yang berperan sebagai post mart, kantor pos pemeriksa ibukota kabupaten/provinsi yang berperan sebagai pusat distribusi dan agen pos yang menjadi mitra perusahaan yang tersebar di seluruh wilayah Indonesia.

4. Relationship: hubungan yang terjadi dengan pelanggan berdasarkan kontrak kerja multiyear.

5. Value configuration: menggunakan layanan logistik internal dan mitra kerja.

6. Capability: memiliki kemampuan jaringan seluruh Indonesia untuk melayani jasa layanan tersebut dengan memanfaatkan jaringan kantor pos yang ada sampai wilayah rural (pedesaan).

7. Partnership: memanfaatkan jaringan internal sendiri untuk melayani jasa layanan tersebut dengan memanfaatkan jaringan kantor pos yang ada dan kerjasama dengan pihak mitra seperti penggunaan fasilitas gudang dan alat angkutan.

8. Cost structure: struktur biaya yang keluar berupa biaya fix cost jaringan termasuk biaya pengadaan MHE (material handling equipment) dan variabel cost seperti biaya operasional sehari hari.

9. Revenue model: sumber pendapatan diperoleh berdasarkan feebased yang tertuang dalam kontrak kerja atau transaksi.

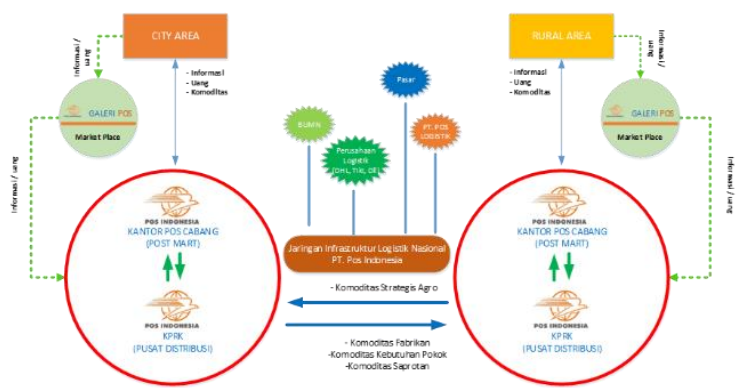

Gambar 4 Model Bisnis Usulan Rural Logistics Ecommerce

Usulan konsep bisnis kedepan PT. Pos Indonesia adalah dengan mengembangkan bisnis rural logistic berbasis $e$-commerce dengan memanfaatkan jaringan fisik PT. Pos Indonesia yang sampai ke pelosok pedesaan dan daerah terpencil. Jaringan logistik yang dimiliki PT. Pos Indonesia dapat dimanfaatkan untuk penyaluran distribusi komoditas strategis agro dari desa ke kota ataupun sebaliknya dari kota ke desa untuk menyalurkan komoditas fabrikan, kebutuhan pokok, dan saprotan yang dibutuhkan oleh masyarakat pedesaan. Selain itu jaringan logistik yang dimiliki oleh PT. Pos Indonesia dapat dimanfaatkan oleh perusahaan BUMN, perusahaan logistik (DHL, TIKI, J\&T dll) untuk menyalurkan kirimannya ke pedesaan ataupun sebaliknya di wilayah Indonesia.

Dengan memanfaatkan jaringan kantor pos cabang yang ada di kecamatan yang berperan sebagai post mart, juga kantor pos yang ada di ibukota kabupaten/provinsi yang berperan sebagai pusat distribusi akan memberikan layanan yang prima bagi masyarakat pedesaan dan sebaliknya untuk menyalurkan kebutuhan pokok dan hasil hasil pertanian. Setiap masyarakat di desa maupun kota dapat membeli kebutuhan pokoknya di outlet-outlet kantor pos yang tersedia di kantor pos cabang kecamatan sampai ibukota kabupaten provinsi. Hal tersebut akan membantu masyarakat tentang ketersediaan barang dan harga yang jauh lebih murah dan terjangkau, sehingga kestabilan harga dapat dikendalikan. Selain itu dengan meningkatnya penggunaan internet dan smartphone oleh masyarakat Indonesia dan didukung dengan program pemerintah tentang road map e-commerce, maka konsep bisnis rural logistic yang diusulkan dapat dikombinasikan dengan platform $e$-commerce. 


\section{KESIMPULAN DAN SARAN}

Berdasarkan hasil analisis yang dilakukan maka usulan konsep bisnis baru PT. Pos Indonesia adalah dengan mengembangkan konsep bisnis rural logistic yang diikuti dengan bisnis platform e-commerce yang berperan sebagai penyedia jasa logistik. Pengembangan bisnis rural logistic tersebut didasarkan pada kekuatan jaringan infrastruktur logistik yang dimiliki oleh PT. Pos Indonesia yang terhubung sampai ke pelosok kecamatan/pedesaan di seluruh Indonesia yang tidak/belum dimiliki oleh perusahaan lain saat ini.

Pengembangan bisnis platform e-commerce yang dikembangkan sendiri oleh PT. Pos Indonesia akan memberi keunggulan kompetitif, dimana PT. Pos Indonesia dapat menghubungkan kebutuhan masyarakat di pedesaan maupun perkotaan dengan sistem berbasis e-commerce.

Dengan adanya jasa layanan rural logsitics $e$ commerce tersebut diharapkan memudahkan jangkauan masyarakat pedesaan maupun perkotaan untuk mendapatkan kebutuhan pokok mereka masingmasing dengan kestabilan harga dan ketersediaan barang yang dapat terkendali, disamping meningkatkan kinerja perusahaan.

\section{REFERENSI}

H.Bask, A., Tinnila, M., \& Rajahonka, M. (1995). Matching service strategies, business models \& modular business processes.

Haoping, D. (2010). Henan Post Logistics Service Innovation and Market Expansion.

Kandampully. (2002). Innovation in logistics services and the new business model.

Osterwalder, A. (2015). Business Model Generation. New Jersey: John Wiley,Inc.

Peraturan Presiden No 26 Tahun 2012. (2012). Cetak Biru Pengembangan Sistem Logistik Nasional.

Peraturan Presiden No 74 Tahun 2017. (2017). Peta Jalan Sistem Perdagangan Nasional Berbasis Elektronik (Road Map E-Commerce). 